M.M. Al-Imam ${ }^{1}$, S.T. Sulaiman ${ }^{2}$

\title{
SQUARE-WAVE VOLTAMMETRIC TRACE DETERMINATION OF AMINOPHYLLINE IN URINE - APPLICATION FOR PHARMACEUTICAL FORMULATION
}

\author{
${ }^{1}$ University of Mosul, Department of Chemistry, College of Education, Mosul, Iraq \\ ${ }^{2}$ University of Mosul, Department of Chemistry, College of Science, Mosul, Iraq \\ E-mail:mohammedalimam@yahoo.com
}

\begin{abstract}
The voltammetric properties of pure aminophylline have been studied by a direct method in the aqueous solution. The substance has revealed a clear and major reduction peak at potential $-0.622 \mathrm{~V}$ against the reference electrode $(\mathrm{Ag} / \mathrm{AgCl} / \mathrm{sat}$. $\mathrm{KCl})$. The calibration curve of aminophylline in the ammonium buffer $\left(\mathrm{NH}_{3} / \mathrm{NH}_{4} \mathrm{Cl}, \mathrm{pH}=10.0\right)$ has been studied under optimum conditions. The relationship has been linearized within the scope of molar concentration $\left(1.09 \times 10^{-6}-2.107 \times 10^{-5}\right)$. The correlation coefficient is $R=0.9903$. The calibration curve has been also studied in the presence of human urine. The standard addition method was used successfully to determine the drug in urine of the patients as well as for the analysis of drug in the tablets, and compared with standard method.
\end{abstract}

Keywords: aminophylline, square wave voltammetry, human urine, drug

\section{INTRODUCTION}

Aminophylline is a chemical compound with the formula $\mathrm{C}_{16} \mathrm{H}_{28} \mathrm{~N}_{10} \mathrm{O}_{5}$. It forms water soluble white or slightly yellowish granules or powder [1]. Aminophylline is a component of the bronchodilator Theophylline with ethylenediamine in 2:1 ratio. Ethylenediamine improves solubility and aminophylline is usually found as a dihydrate [2]. Aminophylline is most common use in the treatment of airway obstruction from asthma or chronic obstructive pulmonary disease (COPD). It is used off-label as a reversal agent during nuclear stress testing. Aminophylline is a nonselective adenosine receptor antagonist and phosphodiesterase inhibitor [3]. Aminophylline has been found to decrease the sedative effects of propofol [4] and to decrease topiramate antiseizure action [5]. Aminophylline relaxes muscles in lungs and chest to allow more air in, decreases the sensitivity of lungs to allergens and other substances that cause inflammation [6]. Aminophylline was originally used in the treatment of bronchial asthma, aminophylline cream have shown to be very capable in cellulite removal and to minimize body fat those areas, it is used as a topical cream [7]. Several methods have been described for its determination. A simple and rapid procedure is described for determination of aminophylline, amobarbital, and ephedrine hydrochloride in a capsule preparation. Aminophylline and amobarbital are determined simultaneously using differential UV spectrophotometry [8]. There is a novel method to determine aminophylline (Ami) with boric acid (BA) by spectrophotometry. The study indicates that at $\mathrm{pH} 12.0$ the absorbance of Ami decreases when BA is added. A simple, rapid, sensitive, and reliable method based on the product of Ami and BA is obtained. Beer's law is obeyed in the range of Ami concentration of $(0.20-200 \mu \mathrm{g} / \mathrm{ml})$. The equation of linear regression is $A=-2.57309 \times 10^{-4}-0.00355 C(\mu \mathrm{g} / \mathrm{ml})$, with a linear correlation coefficient of 0.9969 and relative standard deviation (RSD) $0.28 \%$. The method is successfully applied to the determination of Ami in pharmaceutical samples and mixed serum samples, and average recoveries are in the range of 97.1-105.9\% [9]. Electrochemical behavior of some alkaloids, namely, caffeine, aminophylline, codeine phosphate and papaverine hydrochloride, that are in solution in various combinations or in the presence of other compounds contained in pharmaceuticals or in real samples (urine) has been examined using cyclic voltammetry (CV), square-wave voltammetry (SWV), and differential pulse voltammetry (DPV) on electrochemically activated glassy carbon electrode [10]. There is 
another method used for determination of aminophylline by cathodic stripping voltammetry (CSV) in Britton-Robinson (BR) buffer, pH 7.5 at a hanging mercury drop electrode. The detection limit was $3 \times 10^{-8} \mathrm{M}$ for $60 \mathrm{~s}$ accumulation at $-0.6 \mathrm{~V}$ versus $\mathrm{Ag} / \mathrm{AgCl}$ reference electrode. A linear range was demonstrated up to $5 \times 10^{-7} \mathrm{M}$ using CSV. The electrochemical behavior of aminophylline on glassy carbon electrodes, carbon paste electrode, and on electrodeposited platinum electrodes was investigated in BR buffer ( $\mathrm{pH} 2.59$ and 8.08), phosphate buffer ( $\mathrm{pH} 2.12$ and 6.06), acetate buffer, and aqueous medium containing supporting electrolyte. The effects of factors such as deposition material, time, and concentration of platinum on the precision of the analysis have been explored. A comparison is made between the detection limit of glassy carbon, carbon paste and thin-film modified electrode. The electrooxidation process is applied to the quantitative determination of thigh creams and in the treatment of asthma products. Comparision with the results obtained from high performance liquid chromatography shows good agreement [11].

This paper describes a novel method using square wave voltammetry (SWV) successfully applied to trace determination of aminophylline in both human urine and pharmaceutical formulations.

\section{EXPERIMENTAL}

Apparatus. All the experiments were performed using a 797 VA-Computrace from Metrohm company (Switzerland). A three electrode systems were used. The working electrode was HMDE; the reference electrode was $\mathrm{Ag} / \mathrm{AgCl}$, saturated $\mathrm{KCl}$ electrode and the counter electrode was a Pt-wire one. The $\mathrm{pH}$ measurements were made using a pw 9421-Philips pH-meter.

Reagents. All the chemical reagents used were of analytical grade, aminophylline was obtained from Fluka, solutions of $5.47 \times 10^{-3} \mathrm{M}$ were prepared of $0.250 \mathrm{~g}$ of aminophylline dissolved in deionised distilled water, completing the final volume to $10 \mathrm{ml}$ using a volumetric flask. All the solutions were prepared with deionised distilled water. $\mathrm{NH}_{3} / \mathrm{NH}_{4} \mathrm{Cl}$ buffer $(\mathrm{pH}=7.8)$ solution [12] was prepared by mixing $0.5 \mathrm{ml}$ of $2 \mathrm{M}$ ammonia solution with $9.5 \mathrm{ml}$ of $2 \mathrm{M}$ ammonium chloride solution and then the volume was completed until $100 \mathrm{ml}$, the $\mathrm{pH}$ of buffer will be 7.8. Eufilin tablets from Samara (Iraq).
Procedure. The square wave voltammetry mode was used with deposition time $100 \mathrm{~s}$; condition time $20 \mathrm{~s}$; equilibrium time $5 \mathrm{~s}$; frequency $120 \mathrm{~Hz}$; Scan increament $2 \mathrm{mV} / \mathrm{s}$; conducting potential $0.000 \mathrm{~V}$; Pulse height $0.04 \mathrm{mV}$. The solution was deaerated by passing through it a slow stream of purified nitrogen gas for $240 \mathrm{~s}$ to remove the dissolved oxygen. The square wave voltammogram was recorded on a degassed phosphate buffer solution at $(\mathrm{pH}=7.0)$ $(5 \mathrm{ml})$. The back current was recorded, appropriate amount of aminophylline stock solution were added to this solution to yield the desired concentration and the current - voltage - current was recorded again. A calibration curve was then constructed.

\section{RESULTS AND DISCUSSION}

Structure of aminophylline is shown in Fig. 1.<smiles>Cn1c(=O)c2c(ncn2C)n(C)c1=O</smiles>

Fig. 1. Chemical structure of aminophylline; M.wt $=456.5 \mathrm{~g} / \mathrm{mol} ; \mathrm{m} . \mathrm{p} .=270-274{ }^{\circ} \mathrm{C}$

The electrochemical behavior of aminophylline gives a typical square wave voltammogram of $\left(8.624 \times 10^{-4}\right) \mathrm{M}$ aminophylline in $\mathrm{NH}_{3} / \mathrm{NH}_{4} \mathrm{Cl}$ buffer at $\mathrm{pH}=10$, as shown in Fig. 2 .

It can be seen from Fig. 2 that a well-defined $\mathrm{SWV}$ peak appeared at $-0.622 \mathrm{~V}$ versus $\mathrm{Ag} / \mathrm{AgCl}$, saturated $\mathrm{KCl}$ electrode.

Optimum conditions. The SWV voltammogram of $8.624 \times 10^{-4} \mathrm{M}$ of aminophylline was investigated in $\mathrm{NH}_{3} / \mathrm{NH}_{4} \mathrm{Cl}$ buffer at $\mathrm{pH}=10$, with variation of all the parameters dependent on the measurement; the optimum values obtained are tabulated in Table 1.

Effect of $\boldsymbol{p H}$. The square wave voltammograms of $8.624 \times 10^{-6} \mathrm{M}$ of aminophylline were investigated at different $\mathrm{pH}$ values of $\mathrm{NH}_{3} / \mathrm{NH}_{4} \mathrm{Cl}$ buffer (7-11) using the optimum conditions shown in Table 1. The peak current (Ip) and peak potential (Ep) obtained are shown in Table 2. 
The peak current (Ip) is clearly dependent on the $\mathrm{pH}$, maximum current response was found at $\mathrm{pH}=10$ chosen for the present study; on the other hand, the peak potential (Ep) is found to be greatly dependent on $\mathrm{pH}$ and moves to more negative value with increasing $\mathrm{pH}$ values. Linear plots of Ep versus $\mathrm{pH}$ were obtained as shown in Fig. 3, with correlation coefficient $\mathrm{R}=0.9988$. The slope $\left(-0.0498 \mathrm{~V} \cdot \mathrm{pH}^{-1}\right)$ is very close to the theoretical value (0.059) obtained by Hammett [13].

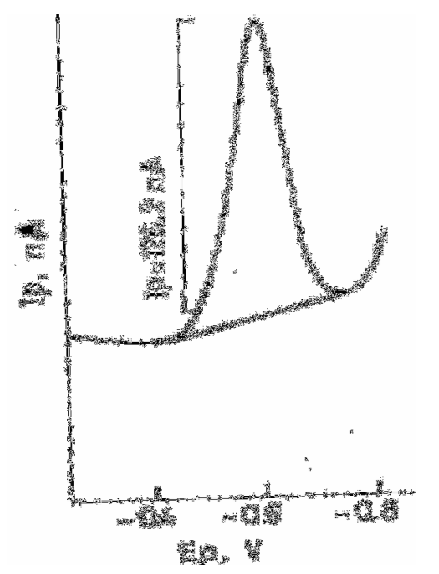

Fig. 2. Square wave voltammogram of $\left(8.624 \times 10^{-4}\right) \mathrm{M}$ aminophylline

Table 1. The optimum values obtained which give either the highest peak current or the best resolution of $8.624 \times 10^{-4} \mathrm{M}$ of aminophylline

\begin{tabular}{|c|c|c|c|}
\hline Condition & Value & Condition & Value \\
\hline $\begin{array}{c}\text { initial } \\
\text { potential }\end{array}$ & $-0.350 \mathrm{~V}$ & Frequency & $120 \mathrm{~Hz}$ \\
\hline $\begin{array}{c}\text { final } \\
\text { potential }\end{array}$ & $-0.820 \mathrm{~V}$ & $\begin{array}{c}\text { Scan } \\
\text { increament }\end{array}$ & $2 \mathrm{mV} / \mathrm{s}$ \\
\hline $\begin{array}{l}\text { deposition } \\
\text { time }\end{array}$ & 100 seconds & $\begin{array}{l}\text { Cond. } \\
\text { Potential }\end{array}$ & $0.00 \mathrm{mV}$ \\
\hline $\begin{array}{l}\text { condition } \\
\text { time }\end{array}$ & 20 seconds & Pulse height & $0.04 \mathrm{mV}$ \\
\hline $\begin{array}{l}\text { equilibrium } \\
\text { time }\end{array}$ & 5 seconds & & \\
\hline
\end{tabular}

Table 2. Effect of pH on SWV peak and peak current of $8.624 \times 10^{-6} \mathrm{M}$ of aminophylline

\begin{tabular}{ccc}
\hline $\mathbf{p H}$ & $\mathbf{E p}, \mathbf{V}$ & $\mathbf{I p , \mathbf { n A }}$ \\
\hline $\mathbf{7}$ & -0.470 & 30 \\
8 & -0.514 & 80 \\
9 & -0.572 & 137 \\
10 & -0.622 & 229.7 \\
11 & -0.665 & 199.4 \\
& $\mathrm{R}$ & 0.9988 \\
& $\mathrm{R}^{2}$ & 0.9976 \\
& slope & -0.0498 \\
& intercept & -0.1204 \\
\hline
\end{tabular}

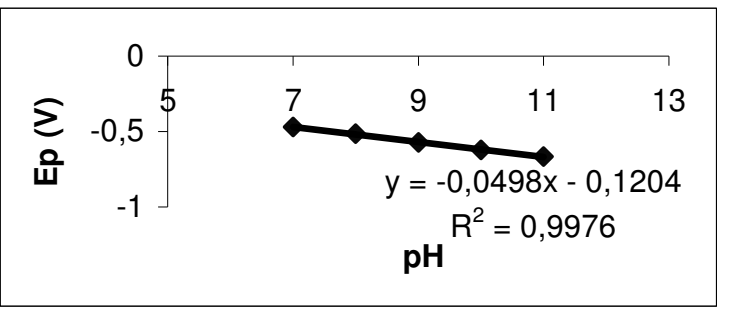

Fig. 3. A relation between $\mathrm{Ep}$ and $\mathrm{pH}$ of $8.624 \times 10^{-6} \mathrm{M}$ of aminophylline

Stability of aminophylline in aqueous ammonium buffer. The square wave voltammograms of $2.1816 \times 10^{-6} \mathrm{M}$ of aminophylline were recorded at different times in $5 \mathrm{ml}$ of $\mathrm{NH}_{3} / \mathrm{NH}_{4} \mathrm{Cl}$ buffer at $\mathrm{pH}=10$ (Table 3).

Table 3. Effect of time on SWV peak of $2.1816 \times 10^{-6} \mathrm{M}$ of aminophylline at $\mathrm{pH}=10$ in aqueous solution

\begin{tabular}{cc}
\hline Time, $\mathbf{m i n}$ & Ip, nA \\
\hline 15 & 86.4 \\
18 & 90.9 \\
21 & 94.9 \\
24 & 99.2 \\
27 & 85.4 \\
30 & 82.6 \\
33 & 88.0 \\
36 & 89.6 \\
39 & 88.4 \\
\hline
\end{tabular}

It can be seen from the Table 3 that aminophylline is stable for more than 39 min what is quite enough for voltammetric measurement.

Analytical Consideration. Using the optimum condition shown in Table 1, a calibration curve was constructed using $5.476 \times 10^{-4} \mathrm{M}$ of a standard aminophylline in $5 \mathrm{ml}$ of aqueous ammonium buffer $(\mathrm{pH}=10)$. Some typical results are listed in Table 4. These solutions were prepared by adding appropriate aliquots of standard aminophylline to the $\mathrm{NH}_{3} / \mathrm{NH}_{4} \mathrm{Cl}$ buffer.

From the results in Table 4 we can see that the values of Ip increase with increasing concentration of aminophylline. Drawing the relation between diffusion current Ip versus concentration of aminophylline gave a straight line with $(\mathrm{R}=0.9903)$ as is explained in Fig. 4.

The plot of peak current (Ip) versus molar concentration of aminophylline is shown in Fig. 4. Regression analysis on standard indicated a straight line. The lowest experimental detection limit was $1.09 \times 10^{-6} \mathrm{M}$. 


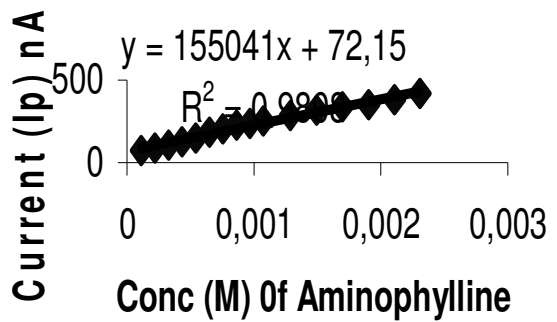

Fig. 4. The relation between peak current (Ip) and concentration of $1.09 \times 10^{-6}-2.107 \times 10^{-5} \mathrm{M}$ of aminophylline at $\mathrm{pH}=10$ in aqueous ammonium buffer

Effect of concentration (calibration curve of aminophylline) with human urine. Using the optimum condition shown in Table 1, a calibration curve was constructed using a serial dilution of a standard aminophylline in the presence of $50 \mu \mathrm{l}$ of human urine. Some typical results are listed in Table 5. These solutions were prepared by adding appropriate aliquots of standard aminophylline to the ammonium $\mathrm{NH}_{3} / \mathrm{NH}_{4} \mathrm{Cl}$ buffer $(5 \mathrm{ml})$ at $\mathrm{pH}=10$.

From the results in Table 5 we can see that the values of Ip increase with increasing concentration of aminophylline. Drawing the relation between diffusion current (Ip) versus concentration gave a straight line with $(R=0.9903)$ as is explained in Fig. 5.

Table 4. Effect of concentration on peak current of $1.09 \times 10^{-6}-2.107 \times 10^{-5} \mathrm{M}$ of aminophylline at $\mathrm{pH}=10$ in aqueous ammonium buffer at $\mathrm{Ep}=-0.606 \mathrm{~V}$

\begin{tabular}{cc}
\hline Addition $\times \mathbf{~ 1 0}^{-\mathbf{6}} \mathbf{M}$ & Ip $(\mathbf{n A})$ \\
\hline 1.09 & 74.1 \\
2.18 & 89.3 \\
3.26 & 108 \\
4.34 & 128.1 \\
5.42 & 149.9 \\
6.49 & 184.4 \\
7.56 & 204.6 \\
8.62 & 225.4 \\
9.68 & 240 \\
10.73 & 252 \\
12.83 & 285 \\
14.91 & 320 \\
16.97 & 337.5 \\
19.02 & 350 \\
21.06 & 380 \\
$\mathrm{R}$ & 0.9903 \\
$\mathrm{R}^{2}$ & 0.9808 \\
intercept & 72.15 \\
\hline
\end{tabular}

The plot peak current (Ip) versus molar concentration of aminophylline is shown in Fig. 5. Regression analysis on standard indicated a straight line. The lowest experimental detection limit was $6.429 \times 10^{-6} \mathrm{M}$.

Measurement of aminophylline concentration in human urine from patients using this drug. Using the optimum condition shown in Table 1, the square wave voltammograms were recorded for $10 \mu 1$ of urine for patients applying aminophylline, after 3-5 h, of each sample in $5 \mathrm{ml}$ of $\mathrm{NH}_{3} / \mathrm{NH}_{4} \mathrm{Cl}$ buffer through measuring diffusion current, the concentration of aminophylline calculated using the standard addition method. The results are tabulated in Table 6.

Table 5. Effect of concentration on peak current of $6.429 \times 10^{-6}-2.5830 \times 10^{-5} \mathrm{M}$ of aminophylline at $\mathrm{pH}=10$ in the presence of human urine at $\mathrm{Ep}=-0.546 \mathrm{~V}$

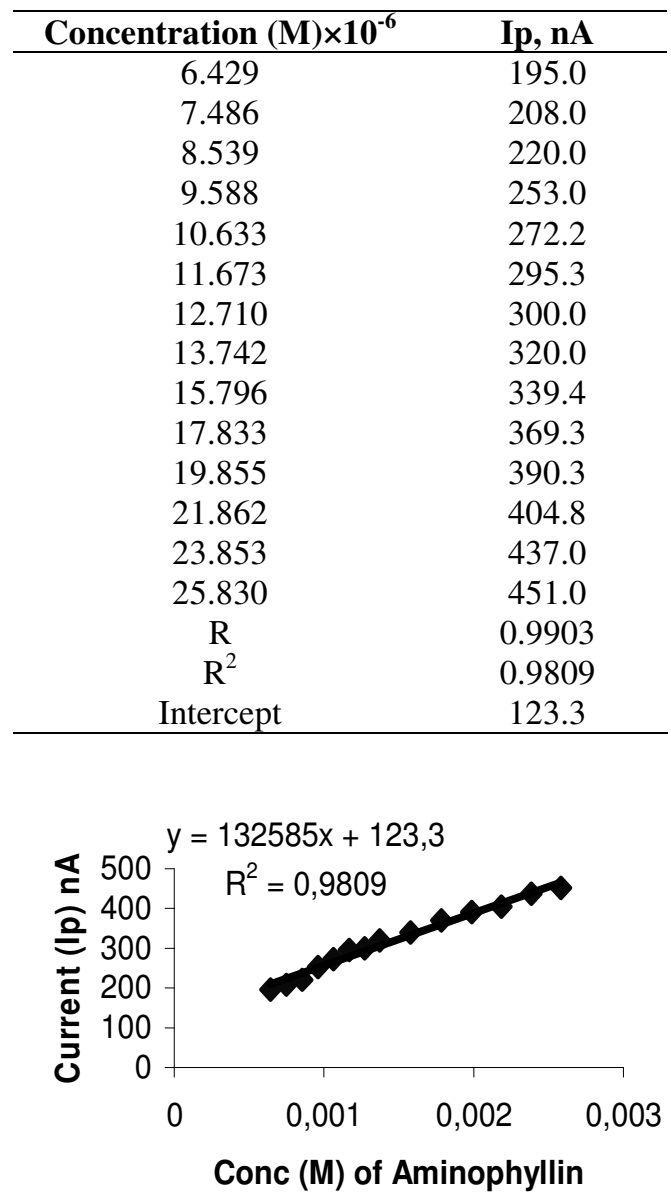

Fig. 5. A relation between peak current (Ip) and concentration of $6.429 \times 10^{-6}-2.5830 \times 10^{-5} \mathrm{M}$ of aminophylline at $\mathrm{pH}=10$ in the presence of human urine at $\mathrm{Ep}=-0.546 \mathrm{~V}$

Measurement of aminophylline concentration in Eufilin tablet. Using the optimum condition shown in Table 1, the square wave voltammograms 
were recorded for $1 \times 10^{-4} \mathrm{M}$ of solution containing Eufilin in $5 \mathrm{ml}$ of $\mathrm{NH}_{3} / \mathrm{NH}_{4} \mathrm{Cl}$ buffer $(\mathrm{pH}=10)$ through measuring diffusion current, the measuring was taken concentration in order to calculate the recovery ratio, and compared the result with standard method, data the obtained are tabulated in Table 7.

Table 6. The results of urine samples for patients who apply aminophylline tablets, in $5 \mathrm{ml}$ of $\mathrm{NH}_{3} / \mathrm{NH}_{4} \mathrm{Cl}$ buffer $(\mathrm{pH}=10)$

\begin{tabular}{cccc}
\hline No & $\mathbf{I p}, \mathbf{n A}$ & Conc., $\left._{\mathbf{M}} \mathbf{M}\right) \times \mathbf{1 0}^{\mathbf{- 6}}$ & Conc., $\mathbf{~ m g} / \mathbf{L}$ \\
\hline 1 & 36.5 & 1.8886 & 0.8621 \\
2 & 42.0 & 2.1732 & 0.9921 \\
3 & 23.0 & 1.1901 & 0.5433 \\
4 & 38.0 & 1.9662 & 0.8976 \\
5 & 34.0 & 1.7592 & 0.8031 \\
6 & 28.0 & 1.4488 & 0.6614 \\
7 & 34.0 & 1.7592 & 0.8031 \\
8 & 37.0 & 1.9145 & 0.8740 \\
9 & 39.0 & 2.0180 & 0.9212 \\
10 & 39.0 & 2.0180 & 0.9212 \\
11 & 31.5 & 1.6299 & 0.7440 \\
\hline
\end{tabular}

Table 7. The data of calibration curve of solution containing $2.181 \times 10^{-6}-2.3078 \times 10^{-5} \mathrm{M}$ of Eufilin

\begin{tabular}{|c|c|c|c|c|c|c|c|}
\hline \multicolumn{5}{|c|}{ By SWV } & \multicolumn{2}{|c|}{ By colorimetric method } & \multirow[b]{2}{*}{ T-test } \\
\hline $\begin{array}{c}\text { Taken } \\
\text { Concentration, } \\
(\mathrm{M}) \times 10^{-6}\end{array}$ & $\begin{array}{c}\text { Found } \\
\text { Concentration, } \\
(\mathbf{M}) \times 10^{-6}\end{array}$ & Ip, nA & \% Recovery & $\%$ Error & $\begin{array}{c}\text { Found } \\
\text { Concentration } \\
(\mathbf{M}) \times 10^{-6}\end{array}$ & \% Recovery & \\
\hline 2.18167 & 2.5380 & 111.5 & 116.3341 & +16.3341 & 2.3944 & 109.75 & 0.924 \\
\hline 3.2660 & 3.4281 & 125.3 & 104.9637 & +4.9637 & 3.5842 & 109.74 & - \\
\hline 4.3460 & 3.9634 & 133.6 & 91.1972 & -8.8027 & 4.7700 & 109.75 & - \\
\hline 7.5605 & 8.8912 & 210.0 & 117.5998 & +17.5998 & 8.2978 & 109.75 & - \\
\hline 8.6236 & 10.5037 & 235.0 & 121.8012 & +21.8012 & 9.4646 & 109.75 & - \\
\hline 9.6825 & 11.7936 & 255.0 & 121.8037 & +21.8037 & 10.6268 & 109.76 & - \\
\hline 19.0286 & 17.5986 & 345.0 & 92.4850 & -7.5149 & 20.8848 & 109.76 & - \\
\hline 21.0615 & 19.2111 & 370.0 & 91.2139 & -8.7860 & 23.1162 & 109.76 & - \\
\hline 23.0789 & 21.1460 & 400.0 & 91.6248 & -8.3751 & 25.3304 & 109.79 & - \\
\hline
\end{tabular}




\title{
Визначення слідових кількостей амінофілліну у людській сечі методом прямокутної вольтамперометрії та його застосування у фармацевтиці
}

\author{
M.M. Al-Imam, S.T. Sulaiman \\ Університет Мосула, Кафедра хімії, Коледж освіти, Мосул, Ірак \\ Університет Мосула, Кафедра хімії, Коледж науки, Мосул, Ірак \\ E-mail: mohammedalimam@yahoo.com
}

\begin{abstract}
Вольтамперометричні властивості чистого амінофілліну досліджено прямим методом у водному розчині. Речовині відповідає чіткий головний пік відновлення при потенціалі -0.622 B відносно референсного електрода ( $\mathrm{Ag} / \mathrm{AgCl} /$ насичений $\mathrm{KCl})$. Калібрувальна крива амінофілліну в амоніачному буфері $\left(\mathrm{NH}_{3} / \mathrm{NH}_{4} \mathrm{Cl}, \mathrm{pH}=10.0\right)$ вивчена за оптимальних умов. Співвідномення було лінеаризовано в рамках молярної концентрації $1.09 \times 10^{-6}-2.107 \times 10^{-5}$. Коеффічієнт кореляції $R=0.9903$. Калібрувальну криву вивчено також у присутності людської сечі. Стандартний метод добавок успішно використано для визначення медикаменту в сечовині паиієнтів, а також для його аналізу в таблетках, і порівняно зі стандартним методом.
\end{abstract}

Ключові слова: амінофіллін, прямокутна вольтамперометрія, людська сеча, медикамент

\section{Определение следовых количеств аминофиллина в человеческой моче методом прямоугольной вольтамперометрии и его применение в фармацевтике}

\section{M.M. Al-Imam, S.T. Sulaiman}

Университет Мосула, Кафедра химии, Колледж образования, Мосул, Ирак Университет Мосула, Кафедра химии, Колледж науки, Мосул, Ирак E-mail:mohammedalimam@yahoo.com

Вольтамперометрические свойства чистого аминофиллина исследованы прямым методом в водном растворе. Веществу соответствует четкий главный пик восстановления при потенциале -0.622 В относительно электрода сравнения ( $\mathrm{Ag} / \mathrm{AgCl} /$ насыщенный $\mathrm{KCl}$ ). Калибровочная кривая аминофиллина в аммиачном буфере $\left(\mathrm{NH}_{3} / \mathrm{NH}_{4} \mathrm{Cl}, \mathrm{pH}=10.0\right)$ изучена при оптимальных условиях. Соотнотение было линеаризовано в рамках молярной концентрации $1.09 \times 10^{-6}-2.107 \times 10^{-5}$. Коэффиџиент коррелячии $R=0.9903$. Калибровочная кривая изучена также в присутствии человеческой мочи. Стандартный метод добавок успешно использован для определения медикамента в моче пациентов, а также для его анализа в таблетках и сравнен со стандартным методом.

Ключевые слова: аминофиллин, прямоугольная вольтамперометрия, человеческая моча, медикамент 


\section{REFERENCES}

1. Essayan D.M. Cyclic nucleotide phosphodiesterases, J Allergy Clin Immunol., 108 (2001) 671.

2. Mader T.J., Smithline H.A., Durkin L., Scriver G. A randomized control trial of intravenous aminophylline for atropine-resistant out-ofhospital asystolic cardiac arrest, Acad. Emerg. Med. J., 10 (2003) 192.

3. Aminophylline Professional Monograph.

4. Turan A., Kasuya Y., Govinda R. et al. The effect of aminophylline on loss of consciousness, bispectral index, propofol requirement, and minimum alveolar concentration of desflurane in volunteers, Anesthesia and Analgesia, 110 (2010) 449.

5. Luszczki J.J., Jankiewicz K., Jankiewicz M., Czuczwar S.J. Pharmacokinetic and pharmacodynamic interactions of aminophylline and topiramate in the mouse maximal electroshock-induced seizure model, Eur. J. Pharmacol., 562 (2007) 53.

6. http://www.igenericdrugs.com/?s=\%20aminop hylline (2014).

7. http://aminophyllinecream.net/ (2013).

8. De Fabrizio F. UV spectrophotometric determination of aminophylline, amobarbital, and ephedrine hydrochloride in an amtiasthma capsule preparation, J. Pharm. Sci., 66 (1997) 811.

9. $L i Q$., Zhang $T$., $L v W$. A novel spectrophotometric method for the determination of aminophylline with boric acid in pharmaceutical and mixed serum samples, Eur. J. Med. Chem., 44 (2009) 1452.

10. Câmpean A., Tertiş M., Săndulescu $R$. Voltammetric determination of some alkaloids and other compounds in pharmaceuticals and urine using an electrochemically activated glassy carbon electrode, Centr. Eur. J. Chem., 9 (2011) 688.

11. Wang Lai-Hao, Wang Chia-Chen Electrochemical oxidation of aminophylline at film platinum electrodes, and its determination in cosmetic and pharmaceutical products, Microchimica Acta, 153 (2006) 95.

12. Perrine D.D. Buffer, $\mathrm{pH}$ and Metal Ion control, Halsted. Press a Division of John Wiley and Sons, Inc., New York, (1974) 138.

13. Hammett L.P. Physical Organic Chemistry, New-York, Ms Graw-Hill, (1940) 184.

Received 26.05.2014, accepted 23.04.2015 